\title{
Primary Right External Iliac Artery to Small Bowel Fistula Treated with Endovascular Graft
}

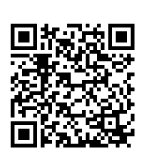

\author{
Mohammad Gerdvisheh and Courtney R Hanak* \\ Department of Surgery, The Jewish Hospital, USA
}

Received: November 10, 2018; Published: December 11, 2018

*Corresponding author: Courtney R Hanak, The Jewish Hospital Department of Surgery, 4777 E Galbraith Rd, Cincinnati, OH, 45236, USA

\begin{abstract}
An arterio-enteric fistula (AEF) is an aberrant connection between the gastrointestinal tract and an artery. This is a rare condition that can present with massive hematochezia that carries a high degree of morbidity and mortality. The annual incidence of primary arterio enteric fistulas is cited to be around 0.007 per million patients [1]. This is a case of a 65 -year-old female with bladder cancer who developed a primary arterio-enteric fistula involving the right external iliac artery after chemoradiation. The fistula was managed with endovascular intervention. Endovascular approach should be considered a viable treatment option arterio-enteric fistula management in life threatened patients.
\end{abstract}

\section{Introduction}

An arterio-enteric fistula (AEF) is an aberrant connection between the gastrointestinal tract and an artery. This is a rare condition that can present with massive hematochezia that carries a high degree of morbidity and mortality. Classically, AEF are categorized in primary versus secondary. Primary AEF are typically a result of trauma, radiation, tumor invasion, or an atherosclerotic aneurysm. A secondary AEF develops as a repercussion of surgical intervention [2]. This is a case of primary arterio-enteric fistula in a 65-year-old female with bladder cancer who had undergone chemoradiotherapy.

\section{Case Report}

This is a 65-year-old female with history of recurrent mixed histology high grade urothelial carcinoma and small cell carcinoma of the bladder on chemotherapy with carboplatin and Gemzar, prior radiation therapy, and a right lower extremity deep vein thrombosis on Xarelto who presented with lower abdominal pain and a gastrointestinal bleed. The abdominal pain began that morning and was sharp and colicky in nature. She felt the urge to have a bowel movement and upon doing so, passed blood per rectum. She was coherent and anxious upon arrival with a BP 85/52 and heart rate of 76 . It should be noted that she was on atenolol and thus did not have an adequate response to hypovolemia. The patient was aggressively resuscitated with initial hemoglobin of 9.1g/dL. On exam, her abdomen was distended with mild diffuse tenderness, but non-peritoneal. The patient with a large volume of hematochezia, with no masses, hemorrhoids, fissures, or source of bleeding noted. She underwent an emergent colonoscopy with a large amount of blood and blood clots throughout the colon. Increasing amounts of blood was noted as the scope was advanced proximal until visualization was complete obscured and the scope was removed.

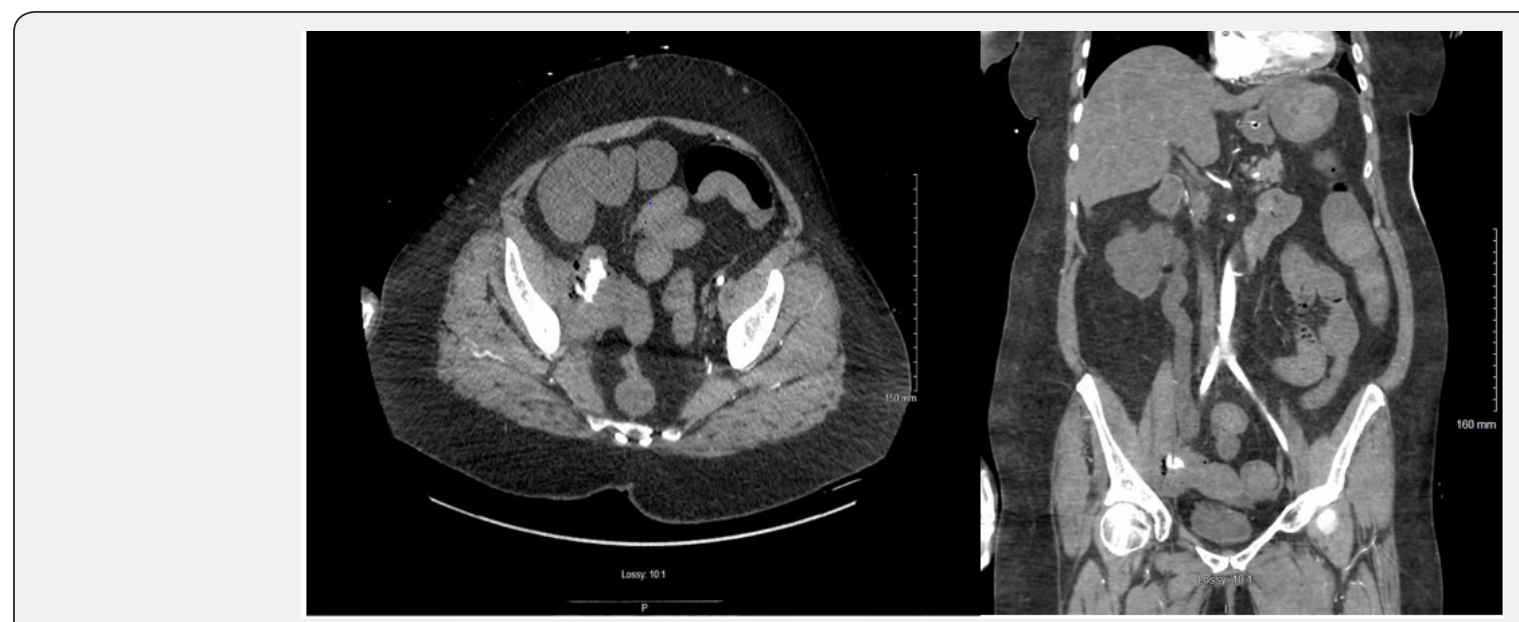

Figure 1: CTA Evidence of AEF. 
The patient was obtunded after the procedure and was intubated for airway protection. She underwent cardiopulmonary arrest with subsequent ACLS and with which she had return of spontaneous circulation. The massive transfusion protocol had already been activated and she was transfused packed red blood cells, platelets, fresh frozen plasma, and cryoprecipitate. Once the patient was stable, she underwent a CTA of the abdomen and pelvis with active extravasation extending from the right external iliac artery into a loop of small bowel in the right lower quadrant. There were several small foci of gas seen surrounding this area and inseparable from a soft tissue density in the right pelvis. It was suspected that the tumor had eroded into the small bowel and the right external iliac artery forming an arterio-enteric fistula with significant active arterial bleeding. The patient had no prior abdominal operations or vascular procedures. At this point, the patient was too unstable to undergo an open operative intervention. The patient was taking to the angiography suite and a $7 \mathrm{mmx} 45 \mathrm{~mm}$ covered stent was placed in the right external iliac artery, occluding the area of active extravasation. The patient was transferred to the ICU for monitoring [3] (Figure 1).

\section{Discussion}

Primary AEF are a rare occurrence and typically a result of trauma, radiation, tumor invasion, or an atherosclerotic aneurysm. The annual incidence of primary arterio enteric fistulas is cited to be around 0.007 per million patients [1]. The patient discussed above developed AEF secondary to tumor invasion. Due to vague presentation $\mathrm{AEF}$ are difficult to recognize leading to high mortality rates. High clinical suspicious is needed in order to prevent mortality. Without prompt surgical intervention, mortality approaches $100 \%$ [4]. With surgical intervention mortality is as high as 50\% [4]. Current there is an absence of recommendations or evidenced based guidelines for a treatment algorithm. As seen in this case an endovascular approach is an acceptable option for life threatening patients (Figure 2).

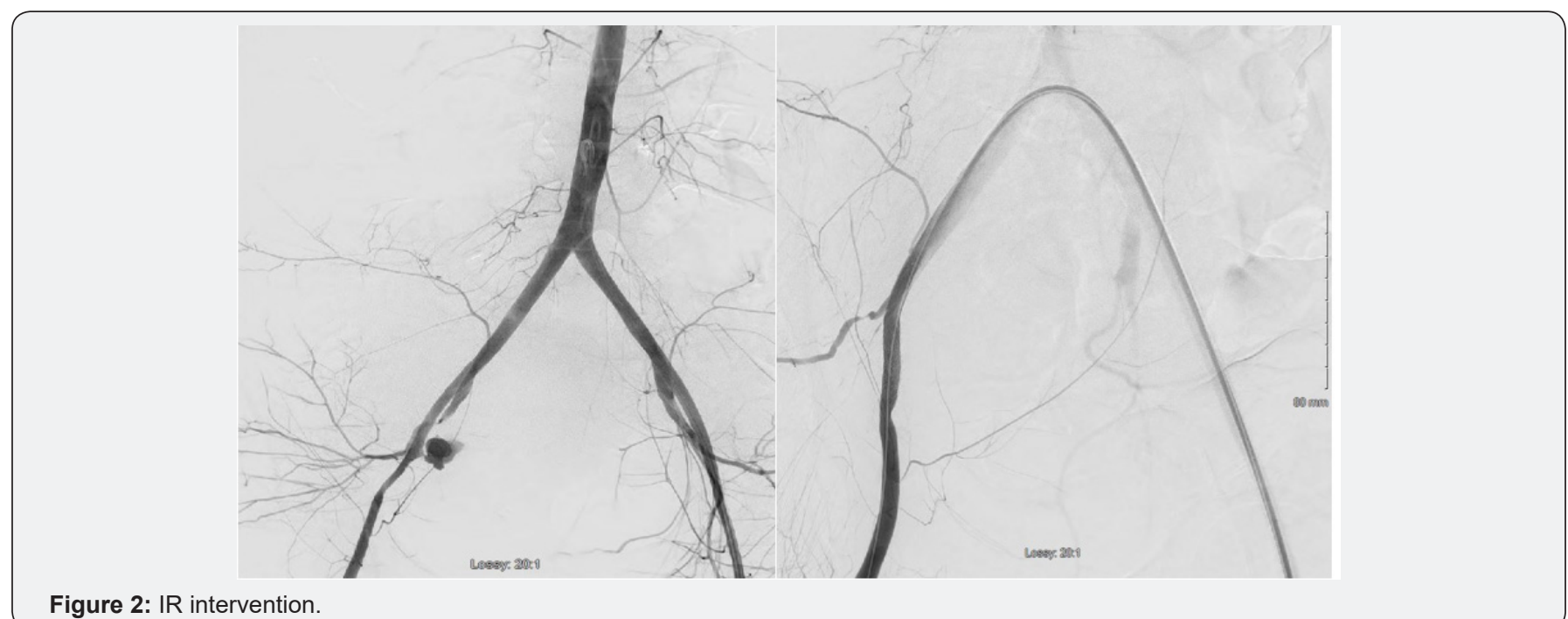

\section{References}

1. Vu QD, Menias CO, Bhalla S, Peterson C, Wang LL, et al. (2009) Aortoenteric fistulas: CT features and potential mimics. Radiographics 29(1): 197-209.

2. Shitara K, Wada R (2009) Gastrointestinal bleeding after aortic surgery: a case report. Cases J 2: 9074.
3. Thomson VS, Gopinath KG, Joseph E, Joseph G (2009) Primary aortoenteric fistula: a rare complication of abdominal aortic aneurysm. J Postgrad Med 55(4): 267-269.

4. Connolly JE, Kwaan JH, Mccart PM, Brownell DA, Levine EF (1981) Aortoenteric fistula. Ann Surg 194(4): 402-412.

\begin{tabular}{l} 
Your next submission with Juniper Publishers \\
will reach you the below assets \\
- Quality Editorial service \\
- Swift Peer Review \\
- Reprints availability \\
- E-prints Service \\
- Manuscript Podcast for convenient understanding \\
- Global attainment for your research \\
- Manuscript accessibility in different formats \\
( Pdf, E-pub, Full Text, Audio) \\
- Unceasing customer service \\
Track the below URL for one-step submission \\
https://juniperpublishers.com/online-submission.php \\
\hline
\end{tabular}

